\title{
POLA BAKTERI AEROB PATOGEN YANG DIISOLASI DARI SAYUR MENTAH SIAP SAJI YANG DIJUAL DI RUMAH MAKAN KAWASAN BOULEVARD MANADO
}

\author{
John Porotu'o \\ Bagian Mikrobiologi Fakultas Kedokteran Universitas Sam Ratulangi Manado \\ Email: pitraporotu’o@yahoo.com
}

\begin{abstract}
Pathogenic aerobic bacteria are the causative agents of food-borne diseases. They belong to the normal flora of digestive tract. This study aimed to obtain the pattern of pathogenic aerobic bacteria isolated from uncooked vegetable sold at several restaurants along Boulevard Manado. The bacteria samples were grown in nutrient seaweed media, MacConkey seaweed, and blood seaweed. The growth of these bacteria was determined by using vibrio cholera, salmonella, shigella, and E. Coli as indicators. Total laboratory investigation of Gram staining and biochemical test in TSIA media, Simon's citrate, semi solid, and pepton water were conducted to obtain the classification of bacteria species. The results showed that the most frequently found bacteria in the uncooked vegetable were Enterobacter aerogenes, Proteus mirabilis, Proteus vulgaris, and Klebsiella ozaena. It is suggested that the restaurant staffs have to improve the hygiene of their uncooked vegetable.
\end{abstract}

Keywords: pathogenic aerobic bacteria, uncooked vegetable

\begin{abstract}
Abstrak: Bakteri aerob patogen merupakan mikroorganisme yang sering menyebabkan penyakit yang ditularkan melalui makanan. Bakteri ini merupakan flora normal pada saluran cerna. Penelitian ini bertujuan untuk mengetahui pola bakteri aerob patogen yang diisolasi dari sayur mentah siap saji dan dikultur pada media nutrient agar, MacConkey agar, dan blood agar terhadap aktivitas bakteri. Penentuan pertumbuhan terhadap bakteri aerob patogen indikator Vibrio cholera, Salmonella, Shigella, dan E. Coli dilakukan melalui pemeriksaan laboratorium total dengan pengecatan Gram serta uji reaksi biokimia pada media TSIA, Simon's Citrate, Semi solid, dan Air pepton untuk menentukan klasifikasi dari spesies bakteri. Hasil penelitian menunjukkan bahwa bakteri yang paling banyak ditemukan ialah Enterobacter aerogenes, Proteus mirabilis, Proteus vulgaris dan Klebsiella ozaena pada sampel sayur mentah siap saji. di beberapa rumah makan kawasan Boulevard Manado. Disarankan pada pengelola rumah makan untuk meningkatkan higiene sayur mentah siap saji.
\end{abstract}

Kata kunci: bakteri aerob patogen, sayur mentah

Bakteri aerob pathogen adalah organisme bersel tunggal yang mengandung RNA dan DNA yang berkembang biak dengan pembelahan diri serta bertumbuh memerlukan oksigen dan menyebabkan penyakit. $^{1} \quad$ Salah satu infeksi yang ditimbulkan oleh bakteri aerob patogen melalui bahan makanan terbukti pada statistik di Amerika Serikat menunjukkan lebih dari 1 di antara 4 kasus penyakit yang ditularkan melalui bahan makan yang tercemar mikroorganisme patogen pada sayuran kotor. Bahan makanan yang terkontaminasi mikroorganisme patogen dapat menyebabkan inflamasi di dalam usus. Gejala paling utama ialah sakit perut, muntah, dan diare, yang gradasinya bervariasi tergantung jenis kuman penyebab. Faktor yang menyebabkan meningkatnya penyakit yang ditularkan 
melalui bahan makanan yang tercemar mikroorganisme patogen sejak 1972 ialah meningkatnya jumlah makanan yang dimakan di luar rumah (kantin, restoran, pinggiran jalan). ${ }^{2-4}$

Di Indonesia peningkatan tempat penjualan makanan jajanan meningkat diikuti dengan pengetahuan masyrakat yang kurang tentang higienis, sehingga banyak kesempatan terjadinya kontaminasi dan menyebabkan timbulnya penyakit seperti di atas. Demikian halnya dengan masyarakat yang ada di kota Manado, banyak ditemukan penjual menu sayur mentah siap saji di beberapa rumah makan di kawasan Boulevard Manado. Berdasarkan fakta di atas perlu dilakukan penelitian tentang kuman aerob patogen dari sayur mentah siap saji yang dijual di rumah makan di kawasan Boulevard Manado.

\section{METODE PENELITIAN}

Penelitian ini bersifat deskriptif prospektif dan dilakukan pada bulan November 2014 - Januari 2015. Sampel berjumlah 40 yang berasal dari sayur mentah siap saji (kol, kacang panjang, ketimun, dan daun kemangi) yang diperoleh dari 5 rumah makan sederhana pinggir jalan (A) dan 5 rumah makan mewah (B) di kawasan Boulevard Manado.

Pengelolaan sampel dilakukan di Laboratorium Mikrobiologi Fakultas Kedokteran Universitas Sam Ratulangi Manado dengan teknik kultur dan reaksi biokimia.

\section{HASIL PENELITIAN}

Hasil pengecatan Gram yang dilakukan pada sampel dari 10 rumah makan memperlihatkan batang Gram-negatif (Tabel 1).

Tabel 1. Sumber sampel, jenis sampel, dan jenis kuman berdasarkan pengecatan Gram dari koloni bakteri

\begin{tabular}{lccccc}
\hline \multirow{2}{*}{ Rumah Makan A } & \multicolumn{2}{c}{ Pertumbuhan Bakteri (Koloni) Pada Media } & \\
& Sampel & Nutrien & Blood & Mac & Pengecatan Gram \\
& Agar & Agar & Conkey & \\
\hline I. Joyo Kosumo & Kol & + & + & + & Batang Gram (-) \\
& Daun Kemangi & + & + & + & Batang Gram (-) \\
& Kacang Panjang & + & + & + & Batang Gram (-) \\
II.Barokah Lamongan & Ketimun & + & + & + & Batang Gram (-) \\
& Kol & + & + & + & Batang Gram (-) \\
& Daun Kemangi & + & + & + & Batang Gram (-) \\
& Kacang Panjang & + & + & + & Batang Gram (-) \\
III.Lamongan Indah & Ketimun & + & + & + & Batang Gram (-) \\
& Kol & + & + & + & Batang Gram (-) \\
& Daun Kemangi & + & + & + & Batang Gram (-) \\
& Kacang Panjang & + & + & + & Batang Gram (-) \\
IV.Seafood Lamongan & Ketimun & + & + & + & Batang Gram (-) \\
& Kol & + & + & + & Batang Gram (-) \\
& Daun Kemangi & + & + & + & Batang Gram (-) \\
& Kacang Panjang & + & + & + & Batang Gram (-) \\
V.Lamongan Kedai Puri & Ketimun & + & + & + & Batang Gram (-) \\
& Kol & + & + & + & Batang Gram (-)
\end{tabular}




\begin{tabular}{|c|c|c|c|c|c|}
\hline & Sampel & $\begin{array}{l}\text { Nutrien } \\
\text { Agar }\end{array}$ & $\begin{array}{l}\text { Blood } \\
\text { Agar }\end{array}$ & $\begin{array}{c}\text { Mac } \\
\text { Conkey }\end{array}$ & \\
\hline \multirow{4}{*}{$\begin{array}{l}\text { I.Rumah Makan Jawa } \\
\text { Timur }\end{array}$} & Kol & + & + & + & Batang Gram (-) \\
\hline & Daun Kemangi & + & + & + & Batang Gram (-) \\
\hline & Kacang Panjang & + & + & + & Batang Gram (-) \\
\hline & Ketimun & + & + & + & Batang Gram (-) \\
\hline \multirow[t]{4}{*}{ II.Ayam Penyet } & Kol & + & + & + & Batang Gram (-) \\
\hline & Daun Kemangi & + & + & + & Batang Gram (-) \\
\hline & Kacang Panjang & + & + & + & Batang Gram (-) \\
\hline & Ketimun & + & + & + & Batang Gram (-) \\
\hline \multirow[t]{4}{*}{$\begin{array}{l}\text { III.Ayam Goreng } \\
\text { Mentega Swadaya }\end{array}$} & Kol & + & + & + & Batang Gram (-) \\
\hline & Daun Kemangi & + & + & + & Batang Gram (-) \\
\hline & Kacang Panjang & + & + & + & Batang Gram (-) \\
\hline & Ketimun & + & + & + & Batang Gram (-) \\
\hline \multirow[t]{4}{*}{$\begin{array}{l}\text { IV.Rumah Makan } \\
\text { Raja Ayam }\end{array}$} & Kol & + & + & + & Batang Gram (-) \\
\hline & Daun Kemangi & + & + & + & Batang Gram (-) \\
\hline & Kacang Panjang & + & + & + & Batang Gram (-) \\
\hline & Ketimun & + & + & + & Batang Gram (-) \\
\hline \multirow[t]{4}{*}{ V.Mawar Sharon } & Kol & + & + & + & Batang Gram (-) \\
\hline & Daun Kemangi & + & + & + & Batang Gram (-) \\
\hline & Kacang Panjang & + & + & + & Batang Gram (-) \\
\hline & Ketimun & + & + & + & Batang Gram (-) \\
\hline
\end{tabular}

Setelah dilakukan pemeriksaan terhadap 40 sampel dari 10 rumah Makan yaitu 5 rumah makan A dan 5 rumah makan B, 40 sampel (100\%) menunjukkan pertumbuhan bakteri (Gambar 1).

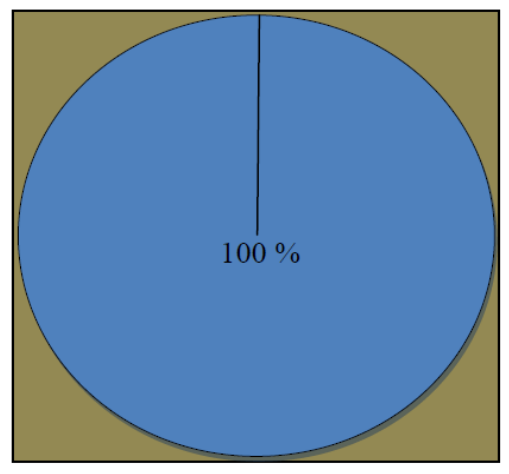

Gambar 1. Distribusi sampel berdasarkan pertumbuhan bakteri pada media nutrien agar, MacConkey, dan Blood Agar. Dari 40 sampel yang diteliti, jumlah bakteri yang tumbuh sebanyak 40 sampel (100 \%)

Dari 40 sampel yang menunjukkan pertumbuhan bakteri, frekuensi masingmasing sampel sama banyak yaitu untuk sampel sayur kol, daun kemangi, kacang panjang, dan ketimun masing-masing 10 sampel (25\%) (Gambar 2).
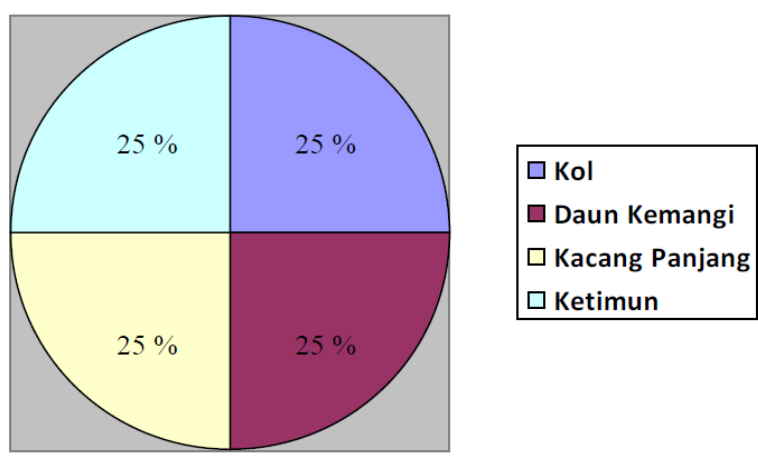

Gambar 2. Distribusi sampel berdasarkan jenis sampel yang menunjukkan pertumbuhan bakteri sama banyak untuk masing-masing sampel (25\%).

\section{Hasil reaksi biokimia}

Hasil penelitian secara keseluruhan dari 40 sampel yaitu 10 sampel kol, 10 sampel daun kemangi, 10 sampel kacang panjang dan 10 sampel ketimun.Setelah pengecatan Gram, dilanjutkan dengan menentukan spesies bakteri melalui reaksi biokimia. 
Pemeriksaan terhadap 40 sampel dari 10 rumah makan yaitu 5 rumah makan A dan 5 rumah makan B, 40 sampel (100\%) menunjukkan pertumbuhan bakteri. Dari reaksi biokimia yang dilakukan terhadap 20 sampel dari rumah makan A, hasil yang dapat diidentifikasi ialah Enterobacter aerogenes terbanyak ditemukan yaitu sebanyak 8 sampel (40\%), diikuti Proteus mirabilis, Proteus vulgaris, dan Klebsiella ozaena masing-masing sebanyak 4 sampel
(20\%) (Tabel 2, Gambar 3). Dari reaksi biokimia yang dilakukan terhadap 20 sampel dari Rumah Makan B, maka hasil yang dapat diidentifikasi adalah Enterobacter aerogenes yang terbanyak ditemukan yaitu sebanyak 12 sampel (60 \%), diikuti Proteus mirabilis sebanyak 4 sampel (20\%) dan Klebsiella ozaena sebanyak 4 sampel (20\%) (Tabel 3 dan Gambar 4). Hasil keseluruhan dapat dilihat pada Tabel 5.

Tabel 2. Spesies bakteri pada kol, daun kemangi, kacang panjang, dan ketimun di rumah makan A

\begin{tabular}{|c|c|c|c|c|c|c|c|c|c|c|c|c|c|}
\hline \multirow[b]{2}{*}{ No } & \multirow[b]{2}{*}{$\begin{array}{l}\text { Spesies } \\
\text { Bakteri }\end{array}$} & \multicolumn{4}{|c|}{ Rekasi Biokimia } & \multicolumn{5}{|c|}{ Jenis Sampel } & \multirow[b]{2}{*}{ Ketimun } & \multirow[b]{2}{*}{ Jumlah } & \multirow[b]{2}{*}{$\%$} \\
\hline & & TSI & Gas & $\begin{array}{l}\mathrm{H} 2 \\
\mathrm{~S}\end{array}$ & MOT & $\begin{array}{l}\text { IN } \\
D\end{array}$ & $\begin{array}{l}\text { S. } \\
\text { C }\end{array}$ & Kol & $\begin{array}{l}\text { Daun } \\
\text { Kemangi }\end{array}$ & $\begin{array}{l}\text { Kacang } \\
\text { Panjang }\end{array}$ & & & \\
\hline 1. & $\begin{array}{l}\text { Enterobacter } \\
\text { Aerogenes }\end{array}$ & $\mathrm{K} / \mathrm{K}$ & + & - & + & - & + & 4 & 2 & 2 & 0 & 8 & 40 \\
\hline 2. & $\begin{array}{l}\text { Proteus } \\
\text { Mirabilis }\end{array}$ & $\mathrm{K} / \mathrm{A}$ & + & + & + & _- & + & 0 & 1 & 1 & 2 & 4 & 20 \\
\hline 3. & $\begin{array}{l}\text { Proteus } \\
\text { vulgaris }\end{array}$ & K/A & + & + & + & + & + & 1 & 2 & 0 & 1 & 4 & 20 \\
\hline 4. & $\begin{array}{l}\text { Klebsiella } \\
\text { ozaena }\end{array}$ & $\mathrm{K} / \mathrm{K}$ & - & - & - & + & + & 0 & 0 & 2 & 2 & 4 & 20 \\
\hline \multicolumn{12}{|c|}{ Jumlah } & 20 & 100 \\
\hline
\end{tabular}

Tabel 3. Spesies bakteri pada kol, daun kemangi, kacang panjang, dan ketimun di rumah makan B

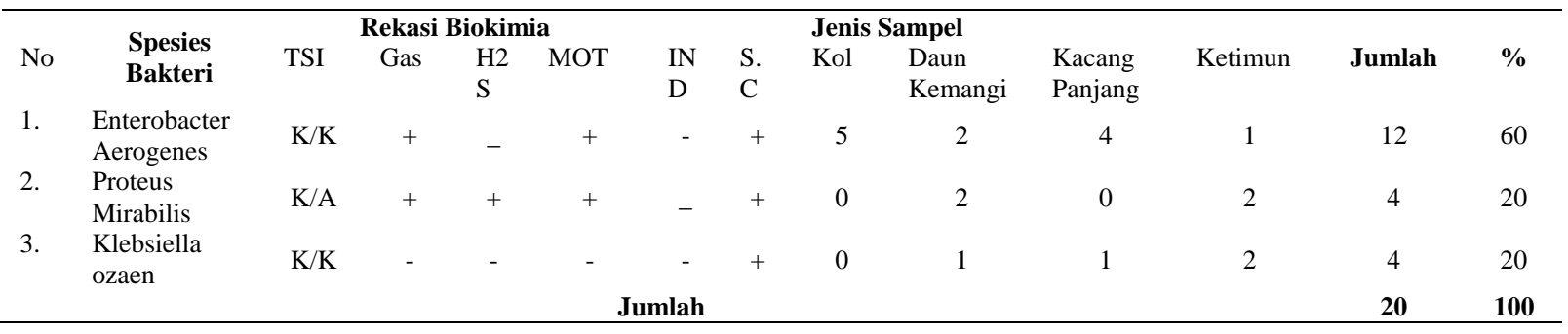

Keterangan :

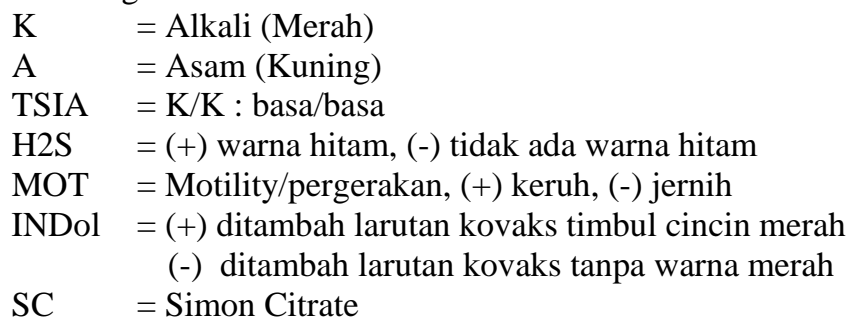

(+) terjadi perubahan warna hijau menjadi biru

(-) hijau, tidak terjadi perubahan warna 

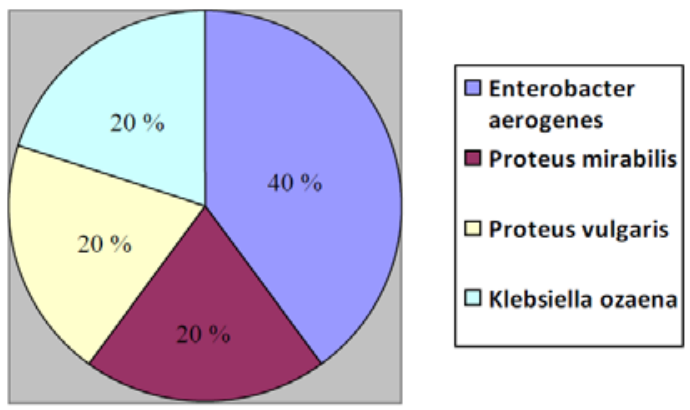

Gambar 3. Distribusi kuman pada sampel dari rumah makan A

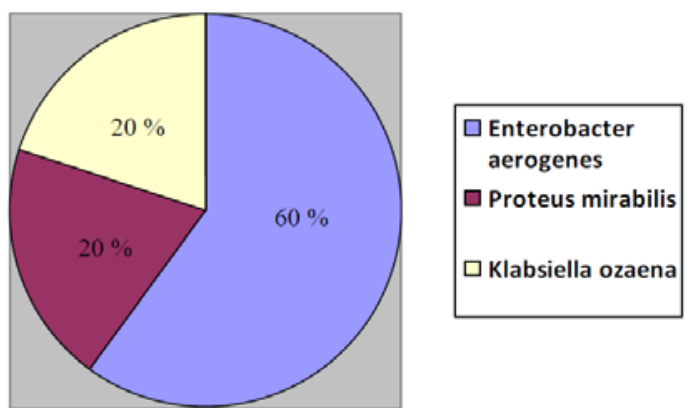

Gambar 4. Distribusi kuman pada sampel dari rumah makan B

Tabel 4. Spesies bakteri yang ditemukan pada rumah makan A dan Rumah Makan B

\begin{tabular}{ccccc}
\hline No & Spesies Bakteri & Rumah Makan A & Rumah Makan B & Sifat Bakteri \\
1. & Enterobacter Aerogenes & + & + & Aerob Patogen \\
2. & Proteus Mirabilis & + & + & Aerob Patogen \\
3. & Proteus Vulgaris & + & + & Aerob Patogen \\
4. & Klebsiella ozaen & + & + & Aerob Patogen \\
\hline
\end{tabular}

Keterangan :

$+=$ Terdapat bakteri

- $\quad$ = Tidak terdapat bakteri

\section{BAHASAN}

Selama kurun waktu periode Juni Juli 2010, telah diteliti sampel berupa sayur mentah siap saji dari 10 rumah makan di kota Manado yaitu 5 rumah makan di kawasan jalan Boulevard (pinggiran jalan) dan 5 rumah makan mewah di kawasan Boulevard yang terdapat dipusat perbelanjaan Mega Mas (Mega Mall) dan Manado Town Square (Mantos).

Penelitian pada 40 sampel sayur mentah siap saji (10 sampel kol, 10 sampel daun kemangi, 10 sampel kacang panjang dan 10 sampel ketimun) dari 5 rumah makan sederhana pinggir jalan (A) dan 5 rumah makan mewah (B).

Bakteri-bakteri yang berhasil diidentifikasi dari sampel yang diambil di rumah makan ialah Enterobacter aerogenes yang terbanyak yaitu pada 8 sampel (40\%), Proteus mirabilis, Proteus vulgaris dan Klebsiella ozaena masing-masing ditemukan pada 4 sampel (20\%). Pada rumah makan B ditemukan bakteri
Enterobacter aerogenes pada 12 sampel (70 \%), Proteus mirabilis pada 4 sampel (20\%) dan Klebsiella ozaena pada 4 sampel (20\%).

Hal yang sama dilaporkan oleh Panther pada tahun 2004 yang melakukan penelitian pada sayur mentah siap saji dengan sampel 2 jenis sayur yang berasal dari 2 rumah makan di kota Manado, mendapatkan bahwa sayur mentah terdapat paling banyak bakteri Enterobacter aerogenes dengan 10 sampel (62\%), Proteus vulgaris 7 sampel (44\%), Proteus mirabilis pada 3 sampel (19\%) dan Klebsiella ozaena pada 2 sampel (13\%). ${ }^{5}$

Spesies Enterobacter adalah anggota flora usus normal, pada umumnya tidak menyebabkan penyakit. Kuman ini menjadi bersifat patogen hanya bila kuman berada di luar usus, yaitu bukan pada lokasi normal tempatnya berada atau dilokasi lain dimana flora normal jarang terdapat. Spesies ini merupakan kuman patogen oportunistik, ketika pertahanan normal 
inang tidak adekuat khususnya pada bayi atau usia lanjut, pada stadium akhir dari penyakit-penyakit lain atau setelah pengobatan dengan imunosupresan. Spesies Enterobacter tidak menyebabkan penyakit yang ditularkan melalui makanan. ${ }^{6-9}$

Spesies Proteus menyebabkan infeksi pada manusia hanya bila kuman ini meninggalkan usus. Kuman ini ditemukan sebagi flora usus normal. Spesies ini merupakan pathogen nosokomial yang penting. ${ }^{10}$

Spesies Klebsiella merupakan anggota flora usus normal, kadang-kadang menyebabkan infeksi saluran kemih dan bektermia pada pasien lemah. Spesies ini tidak menyebabkan penyakit yang ditularkan melalui makanan. ${ }^{10}$

Pada rumah makan B (rumah makan mewah) tidak ditemukan Proteus vulgaris, hal ini karena kuman tersebut dapat berasal dari pekerja yang menyiapkan makanan, atau yang sedang menderita penyakit tersebut.

Dari hasil penelitian ini dapat disimpulkan bahwa bakteri-bakteri yang berhasil diisolasi dari 4 jenis sayur siap saji dari 10 rumah makan yang ditelitu adalah merupakan bakteri aerob pathogen, yang merupakan pathogen pada usus normal.

\section{SIMPULAN}

Dari penelitian yang dilakukan dapat disimpulkan terdapat pola bakteri aerob patogen pada sayur mentah siap saji yang dijual di rumah makan di kawasan Boulevard Manado.

\section{SARAN}

Pentingnya tetap menjaga aspek hygiene dan sanitasi dalam pemilihan bahan makanan, pengolahan makanan dan penyajian makanan. Konsumen dengan daya tahan tubuh rendah sebaiknya tidak mengkonsumsi menu sayur mentah siap saji untuk mencegah paparan dengan kuman aerob pathogen yang terdapat pada sayur tersebut. Sebagai bahan penelitian berikutnya dibeberapa rumah makan di Manado yang tidak hanya terpusat di kawasan Boulevard.

\section{DAFTAR PUSTAKA}

1. Pelczar Jr MJ. Dasar-dasar Mikrobiologi Jilid 2. Jakarta: Universitas Indonesia Press, 1998.

2. Supardi I, Sikanto. Mikrobiologi dalam Pengolahan dan Keamanan Pangan (Edisi Pertama). Bandung: Penerbit Alumni, 1999.

3. Aura. Mencegah Penyakit yang disebabkan Kuman pada Makanan. Edisi 23/TH V/Juni 2003, p. 26.

4. Aura. Agar Sayuran Tidak Membuat Sakit Edisi Ulang Tahun/TH VIII/Januari 2004, p. 34.

5. Panther M. Pola Kuman Aerob Patogen yang Diisolasi dari Sayur Mentah Siap Saji yang dijual di Dua Rumah Makan di Kota Manado. Manado: Program Pasca Sarjana Kedokteran Umum Universitas Sam Ratulangi Manado, 2004.

6. Sujudi H. Mikrobiologi Kedokteran (Edisi Revisi). Jakarta: Bina Rupa Aksara, 1994.

7. Brooks GF, Butel JS, Orston LM, Jawetz, Melnick, Adelberg (editors). Mikrobiologi Kedokteran (Edisi 20). Jakarta: EGC, 1996.

8. Kectum A. Microbiology Introduction for Health Profesionals Enteric (3nd ed.). Medical Microbiology. Canada, 2000.

9. Baron S. Eschericheria, Klebsiella, Enterobacter, Seratia, Citrobacter and Proteus. New York: Churchill Livingstone, 1991.

10. Bacteria and Related Gram Negative Rods (2nd ed.). New York: John Wiley \& Sons, 1998. 